\title{
Muscarinic Receptors Mediating Acid Secretion in Isolated Rat Gastric Parietal Cells Are of M3 Type
}

\author{
A. PFEIFFER, H. ROCHLITZ, B. NOELKE, R. TACKE, U. MOSER, \\ E. MUTSCHLER, and G. LAMBRECHT \\ Medizinische Klinik II, Klinikum Großhadern, Universität München; Institut für Anorganische \\ Chemie, Universität Karlsruhe; Pharmakologisches Institut für Naturwissenschaftler, Universität \\ Frankfurt, Federal Republic of Germany
}

Five subtypes of muscarinic receptors have been identified by pharmacological and molecular biological methods. The muscarinic receptor subtype mediating acid secretion at the level of the parietal cell was unknown. Therefore, this study was performed to characterize muscarinic receptors on rat gastric parietal cells using the 3 subtype-selective antagonists hexahydrosiladifenidol and silahexocyclium, which have high affinity for glandular M3 subtypes, and AF-DX 116, which has high affinity to cardiac M2 receptors. The affinity of these antagonists was determined by radioligand binding experiments. In addition, their inhibitory potency on carbachol-stimulated inositol phosphate production was investigated. Inhibition of carbachol-stimulated aminopyrine uptake was used as an indirect measure of proton production. Both M3 antagonists, hexahydrosiladifenidol and silahexocyclium, had nanomolar affinities for parietal cell muscarinic receptors and potently antagonized inositol phosphate production with nanomolar $\mathrm{Ki}$ values. Silahexocyclium similarly antagonized aminopyrine accumulation while hexahydrosiladifenidol behaved as a noncompetitive antagonist. AF-DX 116 was a low-affinity ligand and a weak competitive antagonist at parietal-cell muscarinic receptors. It was concluded that muscarinic M3 receptors mediate acid secretion probably by activation of the phosphoinositide second messenger system in rat gastric parietal cells.

$\mathbf{M}$ uscarinic cholinergic receptors have originally been subclassified by their different affinities for the nonclassical muscarinic antagonist pirenzepine $(1,2)$, which has high affinity for neuronal M1 and low affinity for non-M1 receptors. Based on molecular cloning of muscarinic receptors, there is now evidence for 5 different subclasses (3-5). Antagonists such as AF-DX 116 (6) were more potent in antagonizing muscarinic actions in cardiac $M 2$ than in smooth muscle M3 (previously termed M2 $\beta$ ) receptors. Compounds such as hexahydrosiladifenidol (HHSiD) and silahexocyclium (SiHC) possess 10-30-fold higher affinity for smooth muscle and glandular M3 than cardiac M2-receptor subtypes $(7,8)$.

We have previously analyzed the radioligand binding properties of muscarinic M2 receptors in homogenates of porcine gastric mucosa (9). These data showed that HHSiD had high affinity (Kd=3 nM) to the majority of mucosal receptors while AF-DX 116 had low affinity $(\mathrm{Kd}=3000 \mathrm{nM}$ ) compatible with the $\mathrm{M} 3$ subtype. However, approximately $25 \%$ of the binding sites in mucosa had low affinity for HHSiD, suggesting the presence of a second subtype of muscarinic receptors. Muscarinic non-M1 receptors in enriched gastric parietal cells (10) activate the phosphoinositol system, which probably provides the second messengers activating acid secretion (10-13). This model system allows a characterization of the muscarinic receptor subtype involved in acid secretion by both functional and radioligand binding studies $(14,15)$. The aim of the present study was to characterize the muscarinic receptor subtype involved in the breakdown of phosphatidylinositols and proton production in isolated rat gastric parietal cells. To this end the inhibitory potencies of prototypic muscarinic M2 and M3 receptor-

Abbreviations used in this paper: dB-cAMP, dibutyryl cyclic adenosine monophosphate; HHSiD, hexahydrosiladifenidol; NMS, ( ${ }^{3} \mathrm{H}$ - $N$-methylscopolamine; SiHC, silahexocyclium.

(ㄷ) 1990 by the American Gastroenterological Association 0016-5085/90/\$3.00 
subtype-selective antagonists were determined in functional and radioligand binding studies.

\section{Methods and Materials}

Rat gastric mucosal cells were isolated and enriched to a parietal cell content of $72 \% \pm 5 \%$ cell number as described (10). Buffer of the following composition was used in all experiments: $\mathrm{NaCl}, 70 \mathrm{mM} ; \mathrm{KCl}, 5 \mathrm{mM}$; sodium phosphate, $1.5 \mathrm{mM}$; HEPES, $50 \mathrm{mM}$; sodium bicarbonate, 20 $\mathrm{mM}$; bovine serum albumin, $0.2 \% ; \mathrm{pH}, 7.4$. Incubations were at $36^{\circ} \mathrm{C}$ in a Dubnoff shaker (Braun, Melsungen, West Germany) under an atmosphere of oxygen and carbon dioxide $[95 \%: 5 \%)$.

\section{Radioligand Binding Experiments}

Binding experiments were performed at a cell concentration of 2 million $/ \mathrm{ml}$ per sample at $36^{\circ} \mathrm{C}$ using $\left({ }^{3} \mathrm{H}\right)-\mathrm{N}$ methylscopolamine (NMS) as radioactive tracer (specific activity 71 and $85 \mathrm{Ci} / \mathrm{mmol}, \mathrm{NEN}$ ) as described previously (10). Specific binding, obtained by subtracting bound radioactivity in the presence of $1 \mu \mathrm{M}$ atropine, was $73 \% \pm 4 \%$ $(\mathbf{n}=9)$ of the total bound. Displacement curves were constructed by displacing $0.25 \mathrm{nM}$ tritiated NMS with 11-13 concentrations of unlabeled ligands (Figure 1). Data were analyzed with the program "Ligand" (16). Receptor density was $8760 \pm 610 /$ cell $[n=5]$.

\section{Inositol Phosphate Determination}

Cells were labeled with tritiated myoinositol, and the formation of inositol monophosphate was determined as described (10) in the presence of $\mathrm{LiCl}(10 \mathrm{mM})$ to obtain a measure of activation of phospholipase C (17).

\section{$\left({ }^{14} \mathrm{C}\right)$ Aminopyrine Accumulation}

$\left({ }^{14} \mathrm{C}\right)$ Aminopyrine accumulation was determined according to the method of Berglindh et al. (14) as described previously [10]. Aminopyrine accumulation is expressed as the ratio of intraglandular radioactivity to that in the supernatant $(10,14)$. The mean aminopyrine ratio was $6.9 \pm 1.3$ $(\mathrm{n}=9$ ) for stimulation by $0.1 \mathrm{mM}$ carbachol, $15 \pm 4$ for 0.1 mM dibutyryl cyclic adenosine monophosphate (dB-cAMP), and $88 \pm 19$ for carbachol plus dB-cAMP $(n=5)$.

\section{Arunlakshana-Schild Plots}

Arunlakshana-Schild plots were calculated to determine antagonist affinities (18) by obtaining dose-response curves for carbachol ( 0.1 or $1 \mu \mathrm{M}$ to $10 \mathrm{mM}$ ) for aminopyrine accumulation and inositol phosphate production in the absence and presence of 3 concentrations of antagonists: HHSiD, 50-500 nM; SiHC, 40-500 nM; AF-DX, 5-100 $\mu \mathrm{M}$. Each experiment was independently performed 3-5 times in duplicates for each point, and mean values were used to calculate Ki values.

\section{Statistical Methods}

Dose-response curves were analyzed with the "Allfit" program of DeLean et al. [19], and the statistics implemented in the program were used to test for parallelism of the curves (19). Data are indicated as means \pm SEM.

\section{Materials}

The sources of chemicals and radiochemicals were as described $(9,10)$. Silahexocyclium was synthesized as described by Tacke et al. (20).
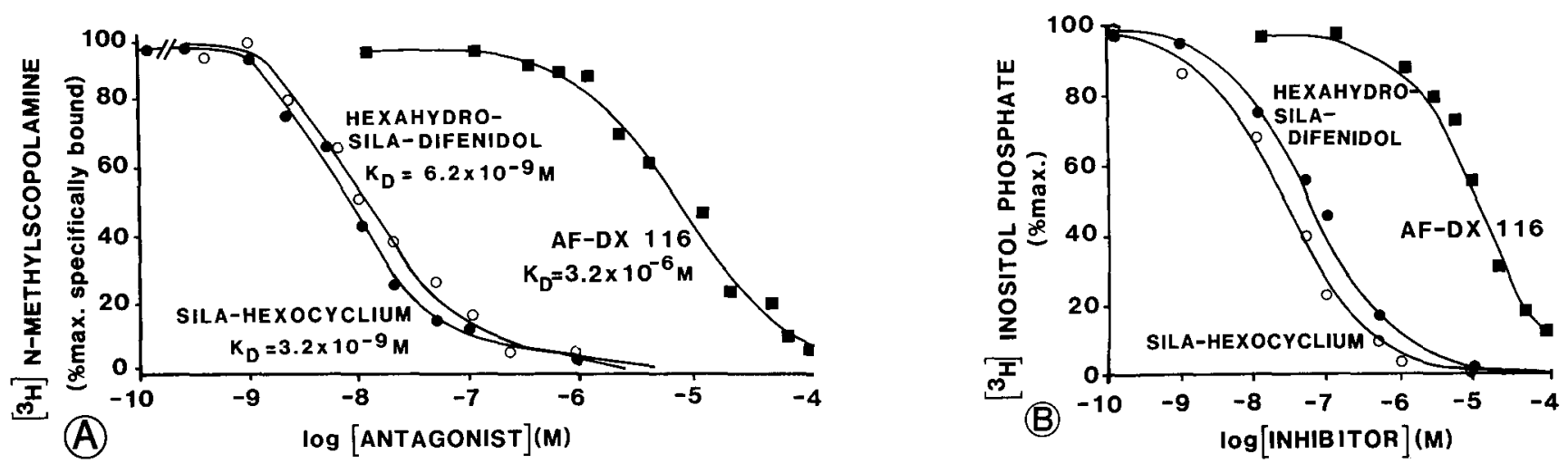

Figure 1. (A) Displacement of NMS by the muscarinic $\mathbf{M}_{3} \beta$-receptor-selective antagonists HHSiD and SiHC and by the cardioselective antagonist AF-DX 116 in rat gastric parietal cells. Each curve represents mean values from 3-4 independent experiments each performed in duplicate. Specific binding was $2153 \pm 518 \mathrm{dpm} / 2$ million cells $(n=5)$. The lines correspond to one-site fits as determined with the curve-fitting program "Ligand" (16). (B) Inhibition of inositol phosphate production stimulated by $0.1 \mathrm{mM}$ carbachol by muscarinic antagonists. Basal and stimulated values for inositol phosphate production were $1436 \pm 436$ and $4740 \pm 956 \mathrm{dpm} /$ tube. The curves correspond to those determined with the "Allfit" program (19). 


\section{Results}

The interaction of the muscarinic antagonists HHSiD, SiHC, and AF-DX 116 with muscarinic receptors in enriched rat gastric parietal cells was studied by radioligand binding experiments. Analysis of the displacement curves against $\left({ }^{3} \mathrm{H}\right) \mathrm{NMS}$ indicated the presence of a single class of binding sites with affinities of $6.2 \pm 1.6$ and $3.2 \pm 0.6 \mathrm{nM}$ for HHSiD and $\mathrm{SiHC}$, respectively (Figure 1). The M2 antagonist AF-DX 116 had a low affinity to the same single site of $3190 \pm 635 \mathrm{nM}$ (Figure 1).

Carbachol $(0.1 \mathrm{mM})$ caused a $3.3 \pm 0.4$-fold $(\mathrm{n}=6)$ stimulation of inositol phosphate formation. None of the antagonists significantly stimulated inositol phosphate production at doses of $0.1 \mathrm{nM}-10 \mu \mathrm{M}(\mathrm{n}=4)$, indicating a lack of partial agonistic activity. The stimulation of inositol phosphate production by carbachol was completely antagonized by HHSiD, SiHC, and AF-DX 116 with IC50 values of $58.2 \pm 7.7 \mathrm{nM}$, $24.7 \pm 3.5 \mathrm{nM}$, and $12.5 \pm 2.6 \mu \mathrm{M}$, respectively (Figure 2). To characterize the type of inhibition and to determine antagonist affinities, an analysis according to Arunlakshana and Schild (18) was performed. Dose-response curves for carbachol were constructed in the absence and presence of the antagonists. Concentrations of $0.05-0.5 \mu \mathrm{M}$ HHSiD and SiHC and 10-100 $\mu \mathrm{M}$ AF-DX 116 caused parallel shifts to the right of the dose-response curves for carbachol, indicative of competitive inhibition. Schild plots of the data

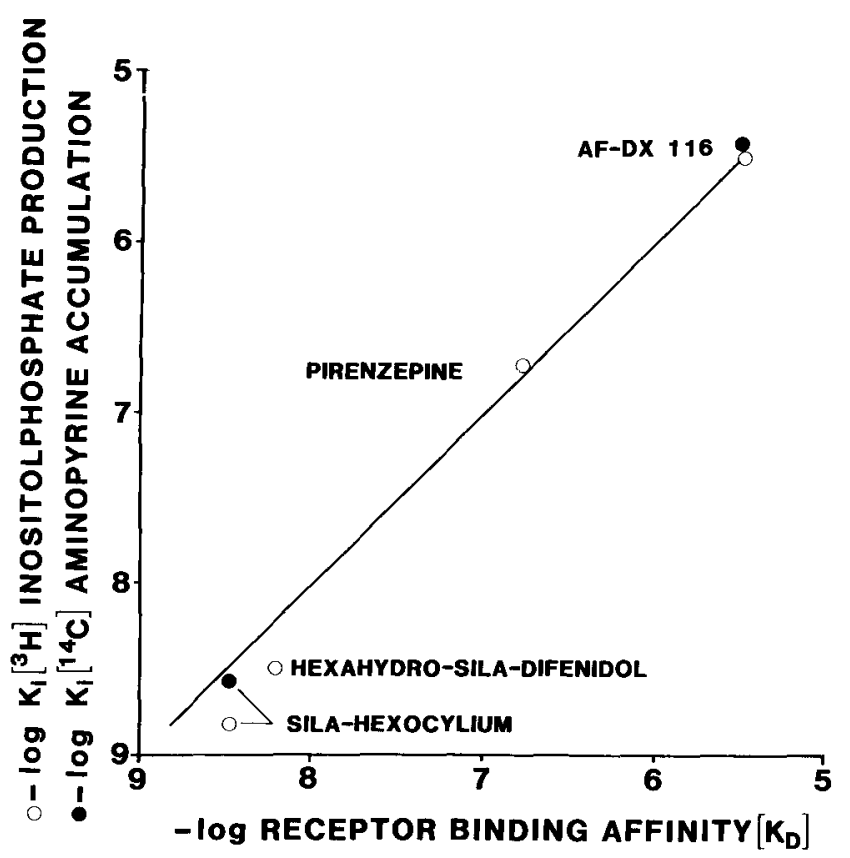

Figure 2. Correlation of receptor binding affinity (Kd) and Ki values for inhibition of carbachol-stimulated aminopyrine uptake or inositol phosphate production for muscarinic antagonists.
Table 1. Antimuscarinic Potencies of Hexahydrosiladifenidol, Silahexocyclium, and AF-DX 116 in Isolated Rat Gastric Parietal Cells

\begin{tabular}{lccc}
\hline & $\begin{array}{c}\text { Inositol } \\
\text { amine binding } \\
\text { Kd }(\mathrm{nM})\end{array}$ & $\begin{array}{c}\text { production } \\
\text { phosphate }\end{array}$ & $\begin{array}{c}\left({ }^{4} \mathrm{C} M\right) \text { aminopyrine } \\
\text { accumulation } \\
K i(n M)\end{array}$ \\
\hline HHSiD & 6.2 & $5.1(-1.16)^{a}$ & $-^{b}$ \\
SiHC & 3.2 & $1.5(-1.11)$ & $2.7[-0.89]$ \\
AF-DX 116 & 3190 & $3100(-0.89)$ & $3200[-0.86)$ \\
\hline
\end{tabular}

${ }^{a}$ Values in parentheses indicate slopes of Schild plots. ${ }^{b}$ Noncompetitive inhibition (see text).

yielded Ki values for HHSiD, SiHC, and AF-DX 116 of $5.1 \mathrm{nM}, 1.5 \mathrm{nM}$, and $3.1 \mu \mathrm{M}$, respectively (Table 1).

The accumulation of the weak base aminopyrine in the acidic intracellular tubulovesical compartment was used to obtain an indirect measure of hydrogen ion production by the isolated cells $(14,15)$. The stimulation by $0.1 \mathrm{mM}$ carbachol was inhibited half maximally by $\mathrm{HHSiD}$ at $67 \pm 8.5 \mathrm{nM}$. However, doseresponse curves for carbachol in the presence of increasing concentrations of HHSiD showed a shift to the right and a flattening of the curves indicative of noncompetitive inhibition. Hexahydrosiladifenidol also inhibited aminopyrine accumulation stimulated by the cell-permeable cAMP analogue dB-cAMP with an IC50 of $443 \pm 47 \mathrm{nM}(\mathrm{n}=4)$. Because dB-cAMP acts intracellularly and thus through a receptorindependent pathway, HHSiD probably interfered with aminopyrine uptake by a receptor-independent mechanism.

Silahexocyclium and AF-DX 116 did not interfere with dB-cAMP-stimulated aminopyrine uptake and inhibited aminopyrine uptake stimulated by carbachol with IC50 values of $24 \pm 3 \mathrm{nM}$ and $15.7 \pm 3.7 \mu \mathrm{M}$, respectively. Increasing concentrations of SiHC and AF-DX 116 caused parallel right shifts of doseresponse curves for carbachol suggesting competitive inhibition. The Ki of SiHC and AF-DX 116 for inhibition of aminopyrine uptake determined by Schild analysis was $2.7 \mathrm{nM}$ and $3.2 \mu \mathrm{M}$ (Table 1).

\section{Discussion}

The present study attempts a classification of the muscarinic receptor subtype that mediates activation of phospholipase $\mathrm{C}$ and acid secretion. In the present study we,used 3 receptor-subtype-selective antagonists that had previously been shown to distinguish cardiac from smooth muscle or glandular muscarinic receptors.

The M3 antagonists, HHSiD and SiHC, had high affinity for muscarinic binding sites on isolated rat 
gastric parietal cells, while the affinity of the M2 antagonist, AF-DX 116, was low.

Antagonist potencies were also assessed in terms of functional parameters. Inositol phosphate is a metabolite of receptor-activated and phospholipase Cmediated breakdown of phosphatidyl inositols which is likely to represent a measure of muscarinic second messenger generation (17). Hexahydrosiladifenidol and SiHC showed similarly high potencies, while AF-DX 116 had low potency, in antagonizing carbacholstimulated inositol phosphate production (Figure 2). All substances behaved as competitive antagonists.

Hexahydrosiladifenidol and SiHC potently inhibited carbachol-stimulated aminopyrine accumulation, which was measured to obtain an estimate of acid secretion $(14,15)$. In contrast, AF-DX 116 again was a weak antagonist. To exclude noncompetitive phenomena, we tested effects on receptor-independent, dBcAMP-stimulated aminopyrine uptake, which should not be affected by the antagonists. Although AF-DX 116 and the quarternary compound, SiHC, did not affect dB-cAMP-stimulated aminopyrine uptake, HHSiD exerted an inhibitory effect. In addition, HHSiD caused a flattening of dose-response curves for carbachol. Because HHSiD was a competitive antagonist of inositol phosphate production, the noncompetitive action is not related to the receptor interaction of the antagonist. The most likely mechanism may be a direct interference of the rather hydrophobic compound with aminopyrine uptake.

The Ki values calculated from the data on inositol phosphate production and aminopyrine uptake were in agreement with $\mathrm{Kd}$ values determined by radioligand binding experiments. This suggests that all 3 effects involved the same type of muscarinic receptor (Table 1; Figure 2). The pharmacological profile of this receptor corresponds to the glandular or M3 subtype of muscarinic receptors (1-9). Therefore, the M3 subtype is likely to mediate muscarinic stimulation of acid secretion via activation of the inositol phosphate system at the parietal cell level.

Baudiere et al. (13) recently determined the potency of HHSiD in isolated rabbit gastric cells with regard to both receptor-binding affinity and inhibition of aminopyrine uptake. The affinity of HHSiD was $<200 \mathrm{nM}$ $\mathrm{Kd}$ in binding studies, and the $\mathrm{Ki}$ for inhibition of aminopyrine accumulation was $79 \mathrm{nM}$. The investigators did not indicate that noncompetitive phenomena were observed. The discrepancy compared with our study may relate to species-specific differences.

The primary structures of 5 different types of muscarinic receptors have been derived from the cloned nucleotide sequences, and their characteristics have been investigated after transfection into various cell types (3-5). The binding data obtained with AF-DX
116, HHSiD, and SiHC for the M3 receptor, which strongly activates phosphoinositide breakdown but does not inhibit adenylate cyclase (5), were similar to those observed in the present study. Thus, the subtype designated either $\mathrm{m} 3$ or mACh-III $(3,4)$ or HM4 (5) most likely corresponds to the M3 receptor present in rat parietal cells. Because this subtype is also present on submandibular and pancreatic cells, it may represent an important gastrointestinal and glandular muscarinic receptor. Isolated rat gastric parietal cells should provide a well-defined system for the molecular, biochemical, and functional characterization of this particular muscarinic receptor subtype.

\section{References}

1. Hammer R, Berrie P, Birdsall NJM, Burgen ASV, Hulme EC. Pirenzepine distinguishes between different subclasses of muscarinic receptors. Nature (London) 1980;283:90-2.

2. Gilbert R, Rattan S, Goyal RK. Pharmacologic identification, activation and antagonism of two muscarine receptor subtypes in the lower esophageal shincter. I Pharmacol Exp Ther 1984;230: 284-91.

3. Akiba I, Kubo T, Maeda A, Bujo H, Nakai J, Mishina M, Numa S. Primary structure of porcine muscarinic acetylcholine receptor III and antagonist binding studies. FEBS Lett 1988:235:25761.

4. Buckley NJ, Bonner TI, Buckley CM, Brann MR. Antagonist binding properties of five cloned muscarinic receptors expressed in CHO-K1 cells. Mol Pharmacol 1989;35:469-76.

5. Peralta EG, Ashkenazi A, Winslow JW, Ramachandran J, Capon D]. The muscarinic receptor subtypes are coupled to different second messenger systems. Nature 1988;334:434-7.

6. Giachetti A, Micheletti R, Montagna E. Cardioselective profile of AF-DX 116, a muscarinic M2 receptor antagonist. Life Sci 1986;38:1663-72.

7. Mutschler E, Lambrecht G. Selective muscarinic agonists and antagonists in functional tests. Trends Pharmacol Sci 1984; (Suppl):39-44.

8. Lambrecht G, Mutschler E, Moser U, Riotte J, Wagner M, Wess J, Gmelin G, Tacke R, Zilch H. Heterogeneity in muscarinic receptors: evidence from pharmacological and electrophysiological studies with selective antagonists. In: Cohen S, Sokolovsky $M$, eds. Proceedings of the international symposium on muscarinic cholinergic mechanisms, Tel-Aviv, Israel, December 1-4, 1986. Tel-Aviv: Freund Publishing, 1987:245-53.

9. Herawi M, Lambrecht G, Mutschler E, Moser U, Pfeiffer A. Different binding properties of muscarinic M2-receptor subtypes for agonists and antagonists in porcine gastric smooth muscle and mucosa. Gastroenterology 1988;94:630-7.

10. Pfeiffer A, Rochlitz H, Herz A, Paumgartner G. Stimulation of acid secretion and phosphoinositol production by rat parietal cell muscarinic M2 receptors. Am J Physiol 1988;254:G622-9.

11. Chew CS, Brown MR. Release of intracellular calcium and elevation of inositol trisphosphate by secretagogues in parietal and chief cells isolated from rabbit gastric mucosa. Biochim Biophys Acta 1986;888:116-25.

12. Puurunen J, Schwabe U. Effect of gastric secretagogues on the formation of inositol phosphates in isolated rat gastric cells of the rat. Br J Pharmacol 1987;90:479-90.

13. Baudiere B, Monferini E, Giraldo E, Ladinsky H, Bali JP. Characterization of the muscarinic receptor subtype in isolated 
gastric fundic cells of the rabbit. Biochem Pharmacol 1987;36: 2957-61.

14. Berglindh T, Helander HF, Oebrink KJ. Effects of secretagogues on oxygen consumption, aminopyrine accumulation and morphology in isolated gastric glands. Acta Physiol Scand 1976;97: 401-14.

15. Soll AH. Physiology of isolated canine parietal cells: Receptors and effectors regulating function. In: Johnson LR, ed. Physiology of the gastrointestinal tract. Vol 1. New York: Raven, 1981:67392.

16. Munson PJ, Rodbard D. Ligand: a versatile approach for characterization of ligand binding systems. Anal Biochem 1980; 107:220-39.

17. Berridge MJ. Inositol trisphosphate and diacylglycerol as second messengers. Biochem J 1984;220:345-60.

18. Arunlakshana $O$, Schild HO. Some quantitative uses of drug antagonists. $\mathrm{Br}$ J Pharmacol 1959;14:48-58.
19. DeLean A, Munson PJ, Rodbard D. Simultaneous analysis of families of sigmoidal curves: application to bioassay, radioligand assay, and physiological dose-response curves. Am J Physiol 1978;235:E97-102.

20. Tacke R, Linoh H, Rafeiner K, Lambrecht G, Mutschler E. Synthese und Eigenschaften des selektiven Antimuscarinikums Sila-Hexocyclium-methylsulfat. J Organomet Chem 1989;359: 159-68.

Received January 3, 1989. Accepted June 21, 1989.

Address requests for reprints to: A. Pfeiffer, M.D., Medizinische Klinik, Klinikum Bergmannsheil, University of Bochum, Gilsingstr. 14, D-4630 BOCHUM-1, Federal Republic of Germany.

This work was supported by the Deutsche Forschungsgemeinschaft (grants Pf 164/3-4 and Ta 75/5-1) and the Fonds der Chemischen Industrie. 